Supporting information

\title{
Indirect Potentiometric pH Detection of Weak Acids with an Absolute Quantitation by Theoretical Approach
}

Shin-Ichi Ohira, ${ }^{\dagger}+{ }^{\ddagger *}$ Yuka Sato $^{\dagger}$, Kazuki Horiuchi ${ }^{\dagger}$,

Charles Phillip Shelori,

†epartment of Chemistry, Kumamoto University, 2-39-1 Kurokami, Kumamoto, 860-8555, Japan.

\#nternational Research Organization for Advanced Science and Technology, Kumamoto University, 2-39-

1 Kurokami Chuo-ku, Kumamoto, 860-8555, Japan

†Department of Chemistry and Biochemistry, University of Texas at Arlington, Arlington, Texas 76019-0065, United States

Corresponding Authors

Shin-Ichi Ohira: ohira@kumamoto-u.ac.jp 


\section{Table of contents}

Figure S1 System photograph of HPLC-pH detector with $\mathrm{pH}$ modifier

Figure S2 Comparison of the responses for $\mathrm{pH}$ electrodes

$\begin{array}{lll}\text { Table S1 Response times of potentiometric pH electrodes } & \text { S-4 }\end{array}$

Figure S3 Relationship between adjusted eluent $\mathrm{pH}$ and ammonia concentration for the $\mathrm{pH}$ modifier $\quad$ S-5

Systematic approach for the theoretical concentrations of thew eluting acids $\quad$ S-6

Figure S4 Baseline stability in a day $\quad$ S-9

Figure S5 Simulation of the relationship between the $\mathrm{HCOOH}$ concentration and solution $\mathrm{pH}$ under the different eluent concentration

Table S2 Separation performances with $\mathrm{pH}$, UV detectors and post-column BTB method

Figure S6 Chromatograms obtained with UV absorbance detector before and after permeator

Figure S7 Chromatograms obtained with $\mathrm{pH}$ detector after baseline modification and UV absorbance detector S-13

$\begin{array}{llr}\text { Figure S8 } & \text { Chromatogram conversions from } \mathrm{pH} \text { to equivalent of acids } & \text { S-14 }\end{array}$

$\begin{array}{llr}\text { Figure S9 Chromatograms for } 0 \text { and } 0.5 \mathrm{mM} \text { standard mixtures } & \text { S-15 }\end{array}$

Figure S10 Chromatogram conversions from (a) $\mathrm{pH}$ to (b) normality and (c) equivalents of acids $\quad$ S-16

$\begin{array}{lll}\text { Figure S10 } & \text { Reproducibility of the } \mathrm{pH} \text { detection with a red wine sample without pretreatment }\end{array}$

Figure S11 Comparison of the effects of SPE for pH-detector and UV direct detection S-18

Table S3 The concentrations of organic acids determined with the present pHD and post-column BTB method S-19 


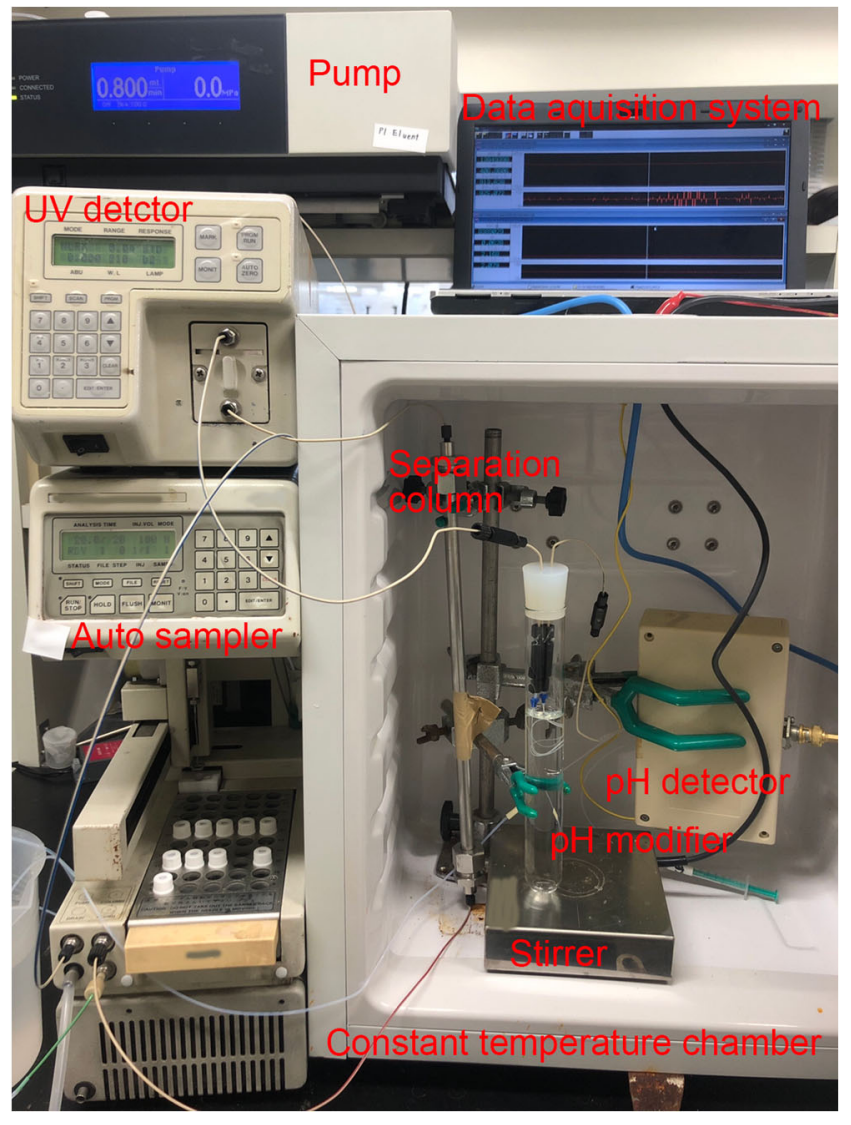

Figure S1 System photograph of HPLC-pH detector with pH modifier 


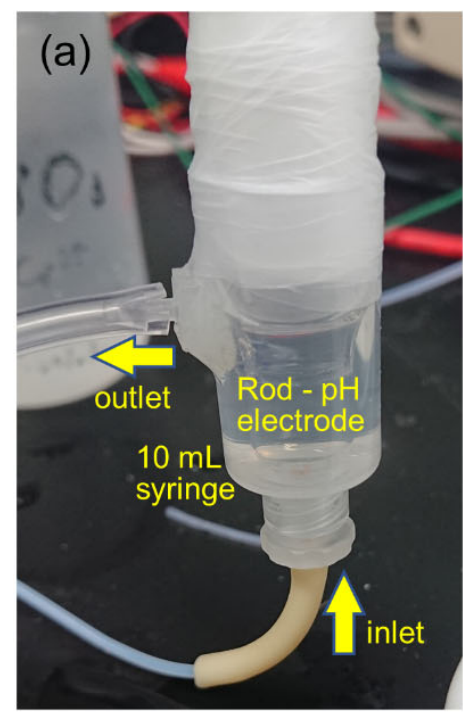

(b)
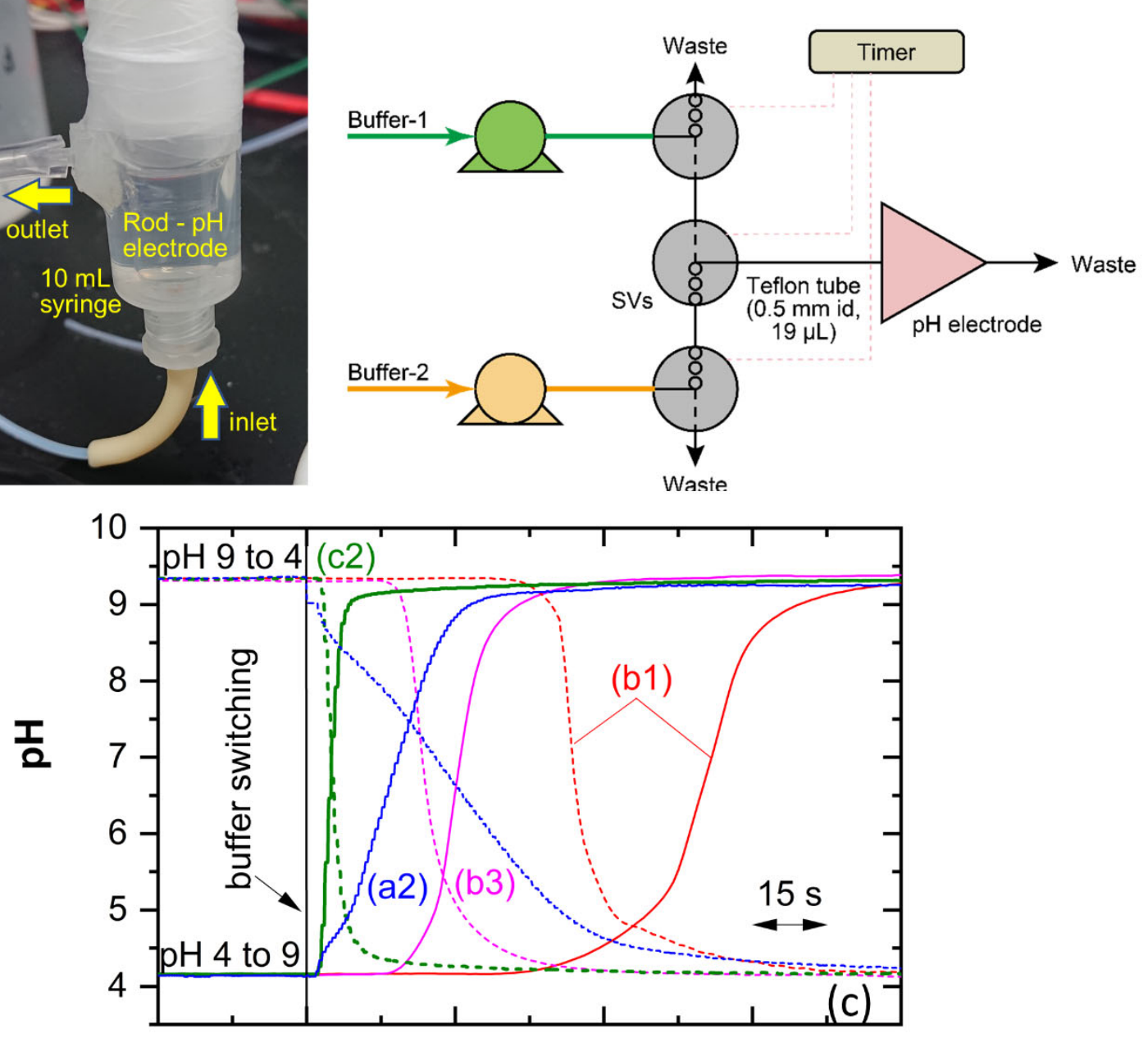

Figure S2 Comparison of the responses for $\mathrm{pH}$ electrodes.

The photo of home-made flow through cell for rod-shape $\mathrm{pH}$ electrode (a) and the schematic flow diagram for the response time study is shown in (b). In the (c), a, b, and c stand for $\mathrm{pH}$ sensors of typical rod-shape, micro flow-through (SCC-200, www.chemical-ins.co.jp), and capillary flowthrough electrodes (UP-100, www.horiba.com). The numbers are flow rates $(\mathrm{mL} / \mathrm{min})$ used for the test. 
Table S1 Response times of potentiometric $\mathrm{pH}$ electrodes

\begin{tabular}{cccc}
\hline & \multicolumn{3}{c}{$90 \%$ Response time, } \\
\cline { 2 - 4 } $\mathrm{pH}$ & $\begin{array}{c}\text { Capillary } \\
2 \mathrm{~mL} / \mathrm{min}\end{array}$ & $\begin{array}{c}\text { Micro-flow } \\
3 \mathrm{~mL} / \mathrm{min}\end{array}$ & $\begin{array}{c}\text { Rod } \\
2 \mathrm{~mL} / \mathrm{min}\end{array}$ \\
\hline $6.86 \rightarrow 4.01$ & 9.6 & 28.5 & 135.7 \\
$4.01 \rightarrow 6.86$ & 8.6 & 27.6 & 95.5 \\
$6.86 \rightarrow 9.18$ & 9.5 & 29.2 & 49.2 \\
$9.18 \rightarrow 4.01$ & 7.1 & 28.5 & 58.4 \\
$4.01 \rightarrow 9.18$ & 9.4 & 29.5 & 35.0 \\
$9.18 \rightarrow 6.86$ & 7.7 & 24.3 & 54.0 \\
\hline
\end{tabular}




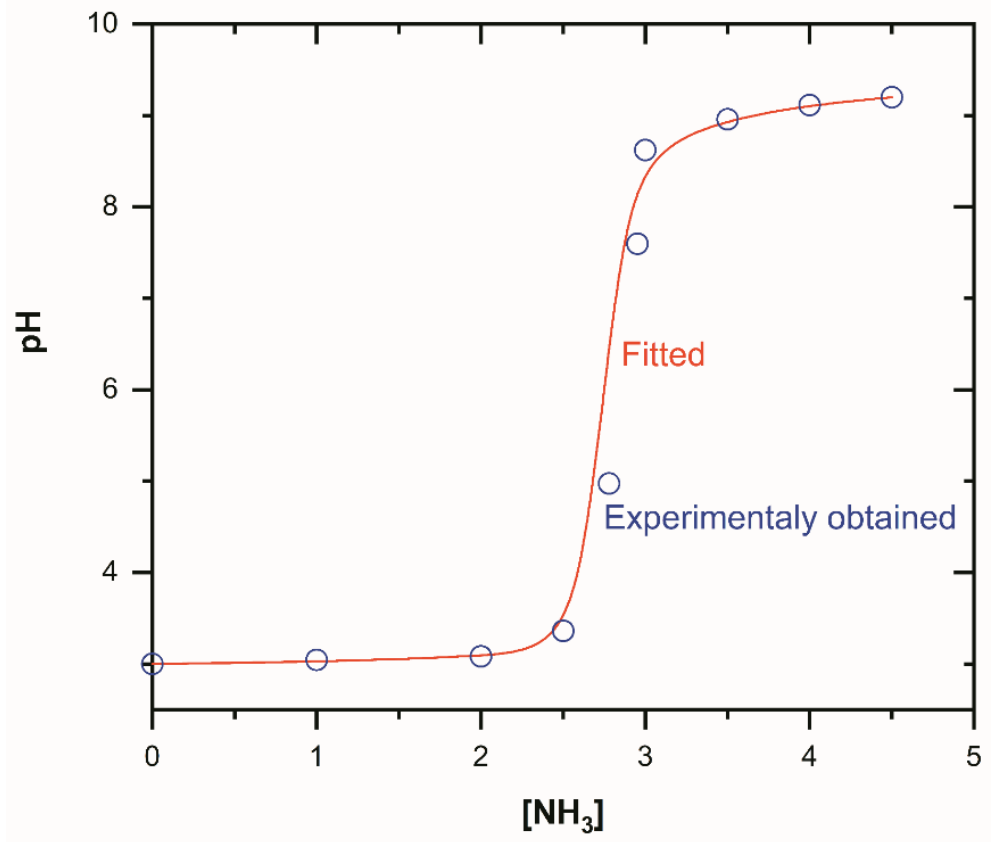

Figure S3 Relationship between adjusted eluent $\mathrm{pH}$ and ammonia concentration for the $\mathrm{pH}$ modifier. Eluent: $3.00 \mathrm{mM} \mathrm{HClO}_{4}$ 


\section{Systematic approach for the theoretical concentrations of thew eluting acids}

The systematic approach was to compute the theoretical concentrations of the eluting acids. The following reactions were considered:

Eluent Dissociation: $\quad \mathrm{HClO}_{4} \rightarrow \mathrm{H}^{+}+\mathrm{ClO}_{4}^{-}$

pH Modifier dissociation equilibrium: $\quad \mathrm{HB}^{+} \rightleftarrows \mathrm{B}+\mathrm{H}^{+} \quad \mathrm{p} K_{\mathrm{a}, \mathrm{HB}}^{\circ}$

Water Dissociation Equilibrium: $\quad \mathrm{H}_{2} \mathrm{O} \rightleftarrows \mathrm{H}^{+}+\mathrm{OH}^{-} \quad \mathrm{p} K^{\circ}{ }_{\mathrm{w}}=14.00$

Monoprotic acid dissociation equilibria: $\mathrm{HA} \rightleftarrows \mathrm{H}^{+}+\mathrm{A}^{-} \quad \mathrm{p} K_{\mathrm{a}, \mathrm{HA}}^{\circ}$

Diprotic acid dissociation equilibria: $\quad \mathrm{H}_{2} \mathrm{~A} \rightleftarrows \mathrm{H}^{+}+\mathrm{HA}^{-} \quad \mathrm{p} K^{\circ}{ }_{\mathrm{a} 1, \mathrm{H} 2 \mathrm{~A}}$

$\mathrm{HA}^{-} \rightleftarrows \mathrm{H}^{+}+\mathrm{A}^{2-} \quad \mathrm{p} K^{\circ}{ }_{\mathrm{a} 2, \mathrm{H} 2 \mathrm{~A}}$

Triprotic acid dissociation equilibria: $\quad \mathrm{H}_{3} \mathrm{~A} \rightleftarrows \mathrm{H}^{+}+\mathrm{H}_{2} \mathrm{~A}^{-} \quad \mathrm{p} K^{\circ}{ }_{\mathrm{a} 1, \mathrm{H} 3 \mathrm{~A}}$

$$
\begin{array}{ll}
\mathrm{H}_{2} \mathrm{~A}^{-} \rightleftarrows \mathrm{H}^{+}+\mathrm{HA}^{2-} & \mathrm{p} K_{\mathrm{a} 2, \mathrm{H} 3 \mathrm{~A}}^{\circ} \\
\mathrm{HA}^{2-} \rightleftarrows \mathrm{H}^{+}+\mathrm{A}^{3-} & \mathrm{p} K_{\mathrm{a} 3, \mathrm{H} 3 \mathrm{~A}}^{\circ}
\end{array}
$$

The equilibrium constants $\left(K_{\mathrm{a}, \mathrm{HB}+}^{\circ}, K_{\mathrm{w}}^{\circ}, K_{\mathrm{a}, \mathrm{A}}^{\circ}\right.$, etc. $)$ are thermodynamic equilibrium constants at infinite dilution and $25{ }^{\circ} \mathrm{C}$. The systems was maintained at $25{ }^{\circ} \mathrm{C}$ so no temperature correction was necessary. Activity coefficients $\left(f_{i}\right)$ were calculated for each ion $(i)$ using the Debye-Hückel equation:

$$
\log f_{i}=\frac{A z_{i}^{2} \sqrt{\mu}}{1+B a_{i} \sqrt{\mu}}
$$

Where $A$ and $B$ are constants of 0.51 and 0.33 , respectively for water at $25{ }^{\circ} \mathrm{C}, z_{i}$ is the charge of the ion, $a_{i}$ is the ion size parameter and $\mu$ is the ionic strength $\left(\mu=0.5 \Sigma c_{i} z_{i}^{2}\right.$, where $c_{i}$ is the concentration of each ion). For practical purposes, $\mu$ was computed at the adjusted baseline $\mathrm{pH}$. The eluent acid fully dissociates, at basic $\mathrm{pH}, \mu$ is approximately equal to the acid concentration plus the hydroxide concentration: $\mu=\left[\mathrm{HClO}_{4}\right]+10^{\mathrm{pH}-14}$. At most concentrations of interest, the eluent concentration will greatly exceed the eluting acid and serve as an ionic strength buffer. The relevant activity corrected equilibrium constant expressions are:

pH modifier dissociation:

$$
K_{\mathrm{a}, \mathrm{HB}+}=K_{\mathrm{a}, \mathrm{HB}+}^{\circ} \frac{f_{\mathrm{HB}+}}{f_{\mathrm{H}+}}=\frac{\left[\mathrm{H}^{+}\right][\mathrm{B}]}{\left[\mathrm{BH}^{+}\right]}
$$

water dissociation equilibrium: $\quad K_{w}=\frac{K^{\circ}{ }_{w}}{f_{\mathrm{H}+} \cdot f_{\mathrm{OH}-}}=\left[\mathrm{H}^{+}\right]\left[\mathrm{OH}^{-}\right]$

monoprotic acid analyte dissociation: $K_{\mathrm{a}, \mathrm{HA}}=K_{\mathrm{a}, \mathrm{HA}}^{\circ} \frac{1}{f_{\mathrm{H}+} \cdot f_{A-}}=\frac{\left[\mathrm{H}^{+}\right]\left[\mathrm{A}^{-}\right]}{[\mathrm{HA}]}$

diprotic acid analyte dissociation: $K_{\mathrm{a} 1, \mathrm{H} 2 \mathrm{~A}}=K_{\mathrm{a} 1, \mathrm{H} 2 \mathrm{~A}}^{\circ} \frac{1}{f_{\mathrm{H}+} \cdot f_{\mathrm{HA}-}}=\frac{\left[\mathrm{H}^{+}\right]\left[\mathrm{HA}^{-}\right]}{\left[\mathrm{H}_{2} \mathrm{~A}\right]}$ 


$$
K_{\mathrm{a} 2, \mathrm{H} 2 \mathrm{~A}}=K_{\mathrm{a} 2, \mathrm{H} 2 \mathrm{~A}}^{\circ} \frac{f_{\mathrm{HA}-}}{f_{\mathrm{H}+} \cdot f_{\mathrm{A} 2-}}=\frac{\left[\mathrm{H}^{+}\right]\left[\mathrm{A}^{2-}\right]}{\left[\mathrm{HA}^{-}\right]}
$$

triprotic acid analyte dissociation: $K_{\mathrm{a} 1, \mathrm{H} 3 \mathrm{~A}}=K_{\mathrm{a} 1, \mathrm{H} 3 \mathrm{~A}}^{\circ} \frac{1}{f_{\mathrm{H}+} \cdot f_{\mathrm{H} 2 \mathrm{~A}-}}=\frac{\left[\mathrm{H}^{+}\right]\left[\mathrm{H}_{2} \mathrm{~A}^{-}\right]}{\left[\mathrm{H}_{3} \mathrm{~A}\right]} \mathrm{Eq}(7)$

$$
\begin{aligned}
K_{\mathrm{a} 2, \mathrm{H} 3 \mathrm{~A}} & =K_{\mathrm{a} 2, \mathrm{H} 3 \mathrm{~A}}^{\circ} \frac{f_{\mathrm{H} 2 \mathrm{~A}-}}{f_{\mathrm{H}+} \cdot f_{\mathrm{HA} 2-}}=\frac{\left[\mathrm{H}^{+}\right]\left[\mathrm{HA}^{2-}\right]}{\left[\mathrm{H}_{2} \mathrm{~A}^{-}\right]} \mathrm{Eq}(8) \\
K_{\mathrm{a} 3, \mathrm{H} 3 \mathrm{~A}} & =K_{\mathrm{a} 3, \mathrm{H} 3 \mathrm{~A}}^{\circ} \frac{f_{\mathrm{HA} 2-}}{f_{\mathrm{H}+} \cdot f_{\mathrm{A} 3-}}=\frac{\left[\mathrm{H}^{+}\right]\left[\mathrm{A}^{3-}\right]}{\left[\mathrm{HA}^{2-}\right]} \quad \mathrm{Eq}(9)
\end{aligned}
$$

The total concentration of a species $\left(c_{i}\right)$ is the sum of each individual form. The Mass balance expressions are:

$\begin{array}{lll}\text { Eluent } & c_{\mathrm{HClO} 4}=\left[\mathrm{ClO}_{4}{ }^{-}\right] & \mathrm{Eq}(10) \\ \text { pH modifier } & c_{\mathrm{B}}=[\mathrm{B}]+\left[\mathrm{HB}^{-}\right] & \mathrm{Eq}(11) \\ \text { monoprotic analyte acid } & c_{\mathrm{HA}}=[\mathrm{HA}]+\left[\mathrm{A}^{-}\right] & \mathrm{Eq}(12) \\ \text { diprotic analyte acid } & c_{\mathrm{HA}}=\left[\mathrm{H}_{2} \mathrm{~A}\right]+\left[\mathrm{HA}^{-}\right]+\left[\mathrm{A}^{2-}\right] & \mathrm{Eq}(13) \\ \text { triprotic analyte acid } & c_{\mathrm{HA}}=\left[\mathrm{H}_{3} \mathrm{~A}\right]+\left[\mathrm{H}_{2} \mathrm{~A}^{-}\right]+\left[\mathrm{HA}^{2-}\right]+\left[\mathrm{A}^{3-}\right] & \mathrm{Eq}(14)\end{array}$

Electroneutrality must be maintained. The respective charge balance equations are:

Monoprotic analyte: $\quad\left[\mathrm{H}^{+}\right]+\left[\mathrm{HB}^{+}\right]=\left[\mathrm{OH}^{-}\right]+\left[\mathrm{ClO}_{4}^{-}\right]+\left[\mathrm{A}^{-}\right] \quad \mathrm{Eq}(15)$

Diprotic analyte: $\left[\mathrm{H}^{+}\right]+\left[\mathrm{HB}^{+}\right]=\left[\mathrm{OH}^{-}\right]+\left[\mathrm{ClO}_{4}{ }^{-}\right]+\left[\mathrm{HA}^{-}\right]+2\left[\mathrm{~A}^{2-}\right] \quad \mathrm{Eq}(16)$

Triprotic analyte:

$$
\left[\mathrm{H}^{+}\right]+\left[\mathrm{HB}^{+}\right]=\left[\mathrm{OH}^{-}\right]+\left[\mathrm{ClO}_{4}^{-}\right]+\left[\mathrm{H}_{2} \mathrm{~A}^{-}\right]+2\left[\mathrm{HA}^{2-}\right]+3\left[\mathrm{~A}^{3-}\right] \quad \mathrm{Eq}(17)
$$

For any protolyzable compound, at a known $\mathrm{pH}$, the fraction of any species, $\alpha_{i}$ from $\alpha_{0}$ (undissociated) to $\alpha_{n}$ (fully dissociated) where $n$ is the number of dissociable protons, is readily computed as:

$$
\alpha_{i}=\frac{\left[\mathrm{H}^{+}\right]^{n-i} \prod_{0}^{i} K_{a, i}}{\sum_{j=0}^{n}\left(\left[\mathrm{H}^{+}\right]^{n-j} \prod_{0}^{j} K_{a, j}\right)}
$$

Where $K_{\mathrm{a}, 0}$ has a value of 1 . Note the denominator is the same regardless of $\alpha_{i}$. For a monoprotic species the respective numerators for $\alpha_{0}$ and $\alpha_{1}$ are $\left[\mathrm{H}^{+}\right]$and $K_{\mathrm{a}}$ with the denominator being $\left[\mathrm{H}^{+}\right]+K$ a. The concentration of any individual species will then just be $c_{\mathrm{A}} \cdot \alpha_{\mathrm{A}, \mathrm{i}} \cdot$

Firstly, $c_{B}$ is calculated. Eq (3) is rearranged and substituted for $\left[\mathrm{OH}^{-}\right]$in Eq (15). Then, $c_{\mathrm{B}} \alpha_{0}$ replaces $\left[\mathrm{HB}^{+}\right]$with $\mathrm{Eq}(18)$ being used to replace $\alpha_{0}$ and $\left[\mathrm{A}^{-}\right]$is 0 : 


$$
\left[\mathrm{H}^{+}\right]+c_{\mathrm{B}} \frac{\left[\mathrm{H}^{+}\right]}{\left[\mathrm{H}^{+}\right]+K_{\mathrm{a}, \mathrm{HB}+}}=\frac{K_{w}}{\left[\mathrm{H}^{+}\right]}+c_{\mathrm{HClO} 4}
$$

Rearranging and solving for $C_{\mathrm{B}}$ :

$$
c_{\mathrm{B}}=\frac{\left[\mathrm{H}^{+}\right]+K_{\mathrm{a}, \mathrm{HB}+}}{\left[\mathrm{H}^{+}\right]}\left(\frac{K_{w}}{\left[\mathrm{H}^{+}\right]}+c_{\mathrm{HClO} 4}-\left[\mathrm{H}^{+}\right]\right)
$$

The permeant base amount may be determined from the measured background $\mathrm{pH}$ $\left(\left[\mathrm{H}^{+}\right]=10^{-\mathrm{pH}} / f_{\mathrm{H}+}\right.$, where $f_{\mathrm{H}+}$ is the activity coefficient of $\left.\mathrm{H}^{+}\right)$and the known eluent acid concentration. Note that $K_{\mathrm{a}, \mathrm{HB}}+$ and $K_{w}$ are the activity corrected equilibrium coefficients in $\mathrm{Eq}(2)$ and $\mathrm{Eq}(3)$.

The concentration of $c$ HA was then determined in a similar fashion as Eq (19) but with additional substitution of $c_{\mathrm{HA}} \alpha_{\mathrm{HA}, 1}$ for [A-] and replacement of $\alpha_{\mathrm{HA}, 1}$ with $\mathrm{Eq}$ (18):

$$
\left[\mathrm{H}^{+}\right]+c_{\mathrm{B}} \frac{\left[\mathrm{H}^{+}\right]}{\left[\mathrm{H}^{+}\right]+K_{\mathrm{a}, \mathrm{HB}+}}=\frac{K_{w}}{\left[\mathrm{H}^{+}\right]}+c_{\mathrm{HClO} 4}+c_{\mathrm{HA}} \frac{K_{\mathrm{a}, \mathrm{HA}}}{\left[\mathrm{H}^{+}\right]+K_{\mathrm{a}, \mathrm{HA}}}
$$

Rearranging and solving for $c_{\mathrm{HA}}$ :

$$
c_{\mathrm{HA}}=\frac{\left[\mathrm{H}^{+}\right]+K_{\mathrm{a}, \mathrm{HA}}}{K_{\mathrm{a}, \mathrm{HA}}}\left(\left[\mathrm{H}^{+}\right]+c_{B} \frac{\left[\mathrm{H}^{+}\right]}{\left[\mathrm{H}^{+}\right]+K_{\mathrm{a}, \mathrm{HB}+}}-\frac{K_{w}}{\left[\mathrm{H}^{+}\right]}-c_{\mathrm{HClO} 4}\right)
$$

The concentration of any polyprotic may be calculated similarly with the right hand term in parentheses being the same. The left hand term will simply be $\left[\left(\alpha_{1}+2 \alpha_{2} \ldots+n \alpha_{n}\right)\right]^{-1}$ or recognizing that only $\alpha_{0}$ is absent:

$$
c_{\mathrm{H}_{n} \mathrm{~A}}=\frac{\sum_{j=0}^{n}\left(\left[\mathrm{H}^{+}\right]^{n-j} \Pi_{0}^{j} K_{\mathrm{a}, j}\right)}{\sum_{j=0}^{n}\left(j \cdot\left[\mathrm{H}^{+}\right]^{n-j} \Pi_{0}^{j} K_{\mathrm{a}, j}\right)}\left(\left[\mathrm{H}^{+}\right]+c_{\mathrm{B}} \frac{\left[\mathrm{H}^{+}\right]}{\left[\mathrm{H}^{+}\right]+K_{\mathrm{a}, \mathrm{HB}+}}-\frac{K_{W}}{\left[\mathrm{H}^{+}\right]}-c_{\mathrm{HClO} 4}\right)
$$

Note that if all $K_{\mathrm{a}}$ 's of any eluting acid are relatively far from the operating $\mathrm{pH}$ and the concentration of the analyte does not exceed the equivalence point of the free base, B, then the left hand terms of Eq (22) and Eq (23) are approximately 1 such that all analytes have the same response:

$$
c_{\mathrm{HA}}=\left(\left[\mathrm{H}^{+}\right]+C_{\mathrm{B}} \frac{\left[\mathrm{H}^{+}\right]}{\left[\mathrm{H}^{+}\right]+K_{\mathrm{a}, \mathrm{HB}+}}-\frac{K_{w}}{\left[\mathrm{H}^{+}\right]}-c_{\mathrm{HClO} 4}\right)
$$

In other words, the $\mathrm{pH}$ is buffered solely by the permeant base and the measured response is the titration of the free base with the eluting analyte acid. 


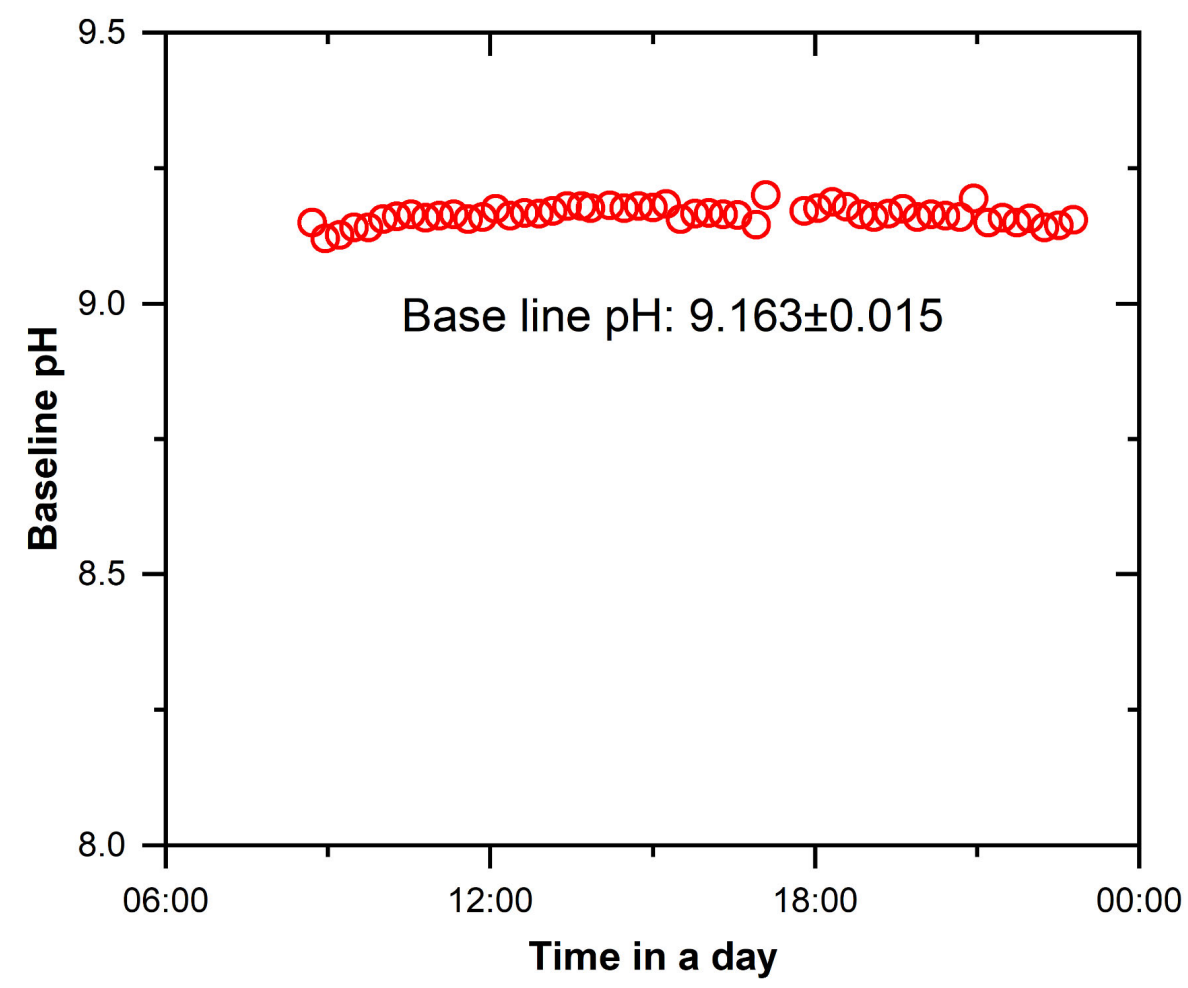

Figure S4 Baseline stability in a day. 


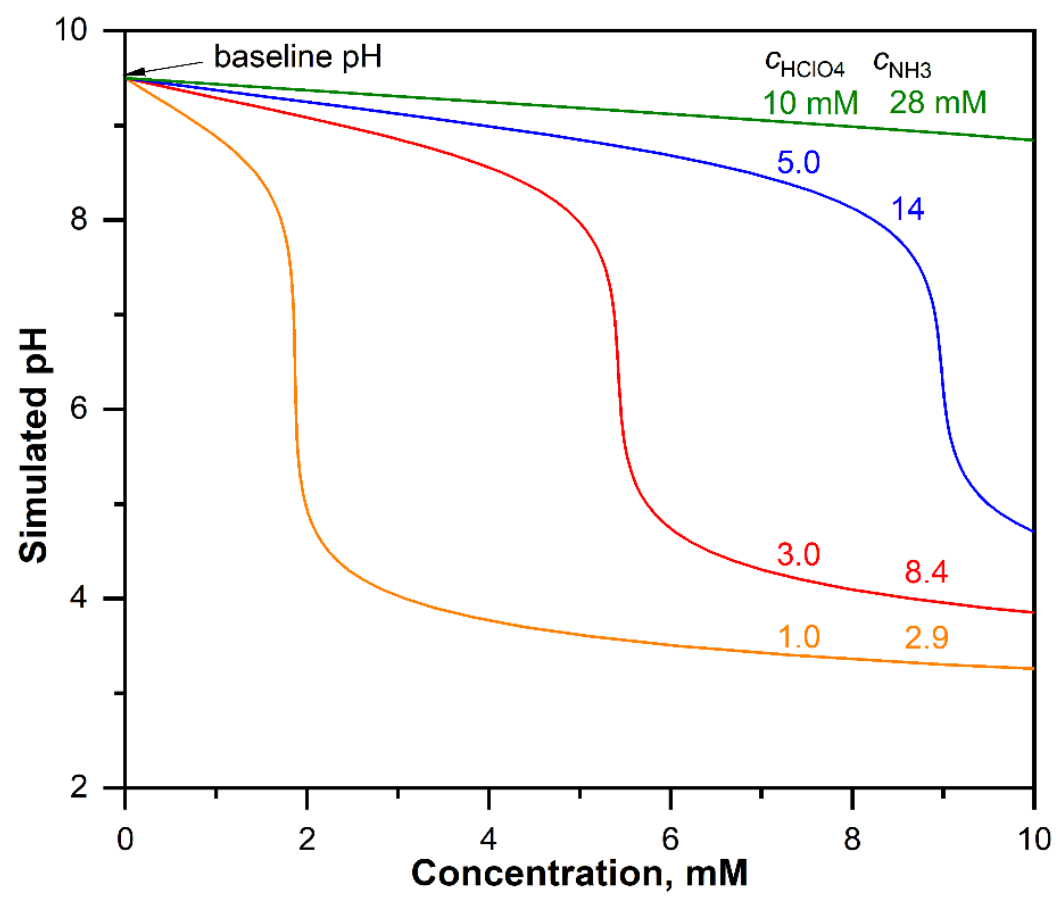

Figure S5 Simulation of the relationship between the formate concentration and solution $\mathrm{pH}$ under the different eluent concentration 
Table S2 Separation performances with pH, UV detectors and post-column BTB method

\begin{tabular}{|c|c|c|c|c|c|c|c|c|c|}
\hline & $\mathrm{pH}$ & & & UV & & & ВТВ & & \\
\hline & R.T. & $W_{1 / 2}$ & $R$ & R.T. & $W_{1 / 2}$ & $R$ & R.T. & $W_{1 / 2}$ & $R$ \\
\hline Citrate & 8.172 & 0.235 & \multirow{3}{*}{$\begin{array}{l}0.77 \\
1.52\end{array}$} & 7.778 & 0.152 & \multirow{3}{*}{$\begin{array}{l}1.51 \\
2.44\end{array}$} & 7.528 & 0.182 & \multirow[b]{2}{*}{0.63} \\
\hline & 8508 & 02767 & & 8157 & 0144 & & 7743 & 0218 & \\
\hline Malate & 9.142 & 0.215 & & 8.778 & 0.156 & & 8.372 & 0.281 & 1.49 \\
\hline$y$ in UVD & & & 3.17 & 9.603 & 0.167 & $\begin{array}{l}3.01 \\
1.20\end{array}$ & & & 2.15 \\
\hline Succinate & 10.323 & 0.225 & & 9.955 & 0.178 & \multirow{2}{*}{2.36} & 9.467 & 0.321 & \multirow{2}{*}{1.36} \\
\hline Lactate & 10.982 & 0.253 & 1.63 & 10.625 & 0.157 & & 10.225 & 0.337 & \\
\hline$z$ in UVD & & & 3.20 & 10.973 & 0.206 & $\begin{array}{l}1.13 \\
3.09\end{array}$ & & & 2.43 \\
\hline Acetate & 12.378 & 0.262 & 1.90 & 12.022 & 0.194 & \multirow[t]{2}{*}{2.40} & 11.687 & 0.372 & \multirow[t]{2}{*}{1.46} \\
\hline Pyroglutamate & 13.257 & 0.285 & & 12.895 & 0.236 & & 12.658 & 0.412 & \\
\hline
\end{tabular}

*R.T.: Retention time, $W_{1 / 2}$ : Half height peak width, $R$ : Resolution 


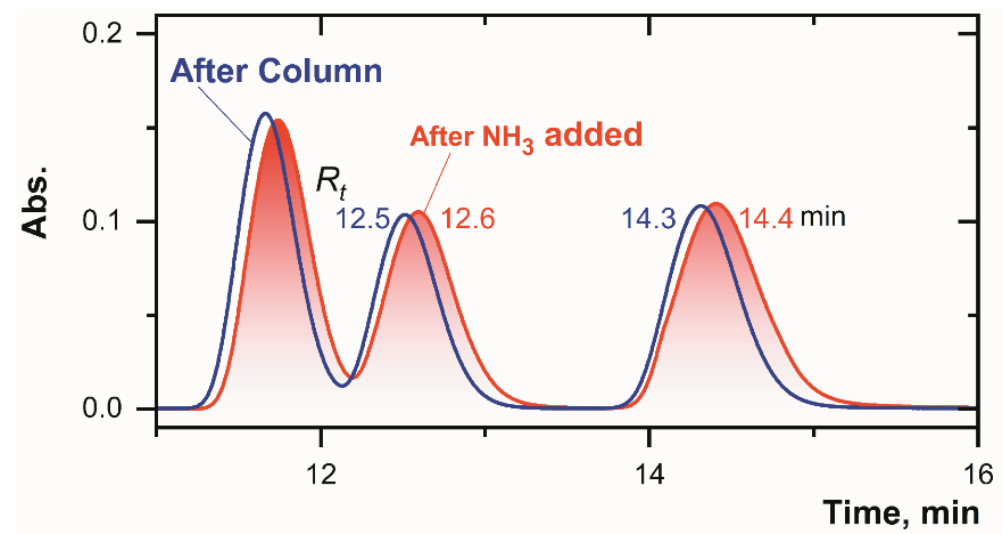

Figure S6 Chromatograms obtained with UV absorbance detector before and after permeator. The peaks are formate, acetate, and propionate from left to right. The concentration is $10 \mathrm{mM}$. 


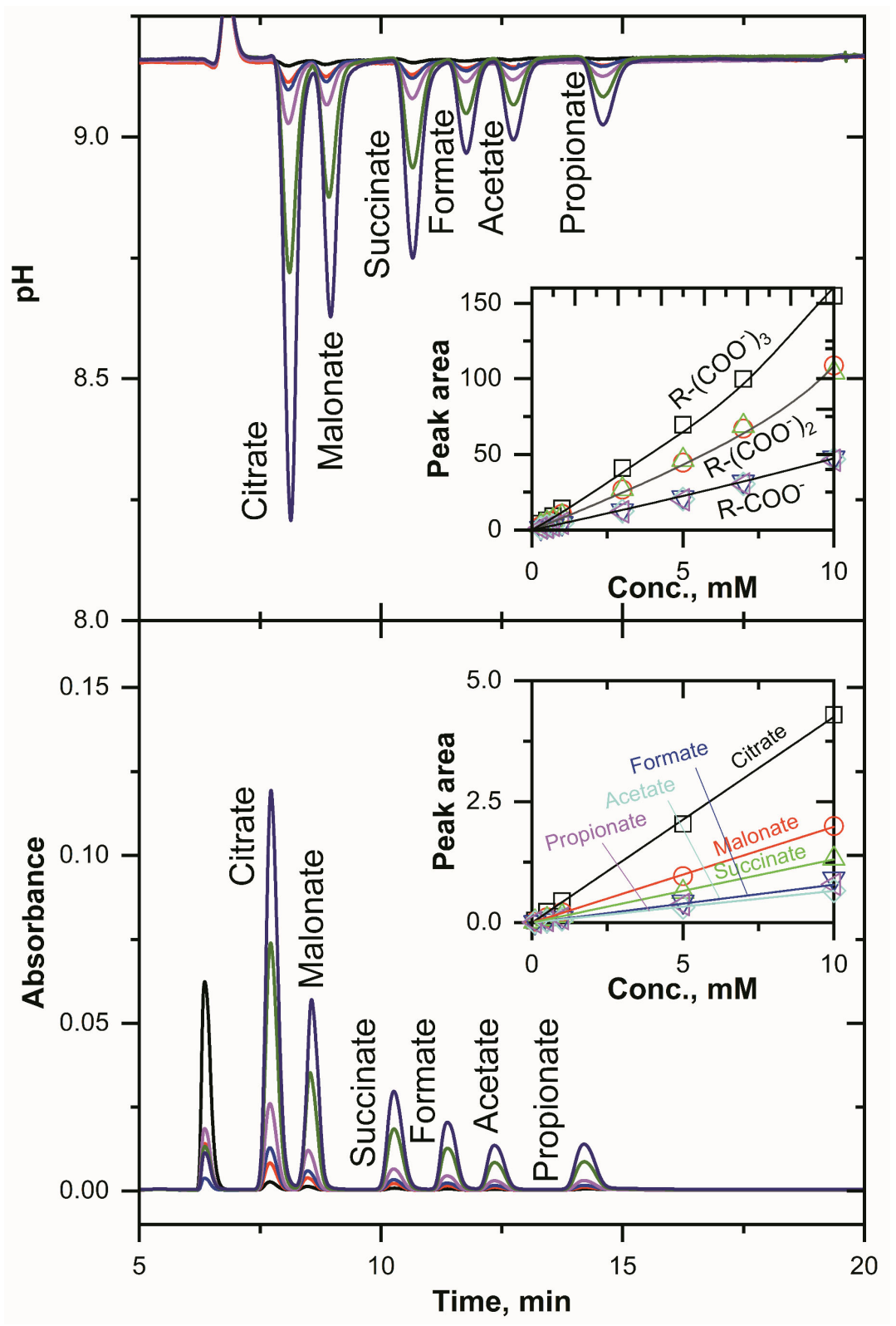

Figure S7 Chromatograms obtained with $\mathrm{pH}$ detector after baseline modification and UV absorbance detector. The inset shows the calibration curves. The details of the conditions are in the main text. 


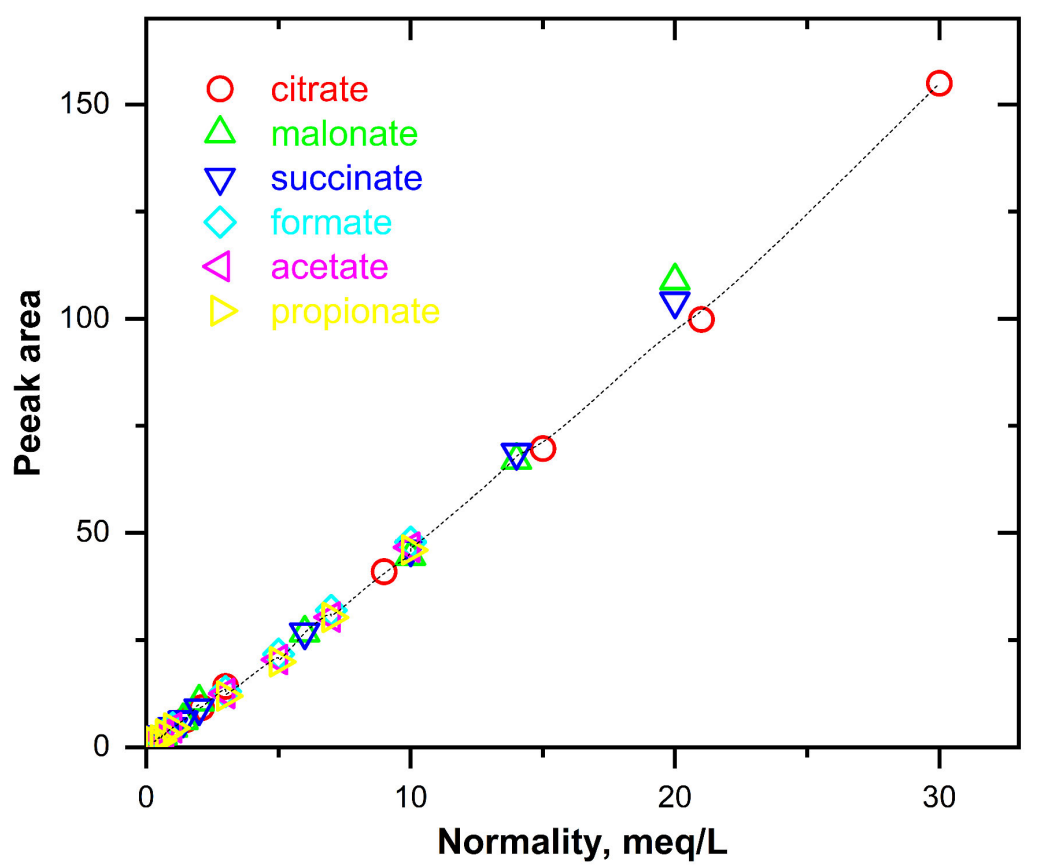

Figure S8 Calibration curve with normality. The curve was drawn with the data shown as inset in Figure S7. 


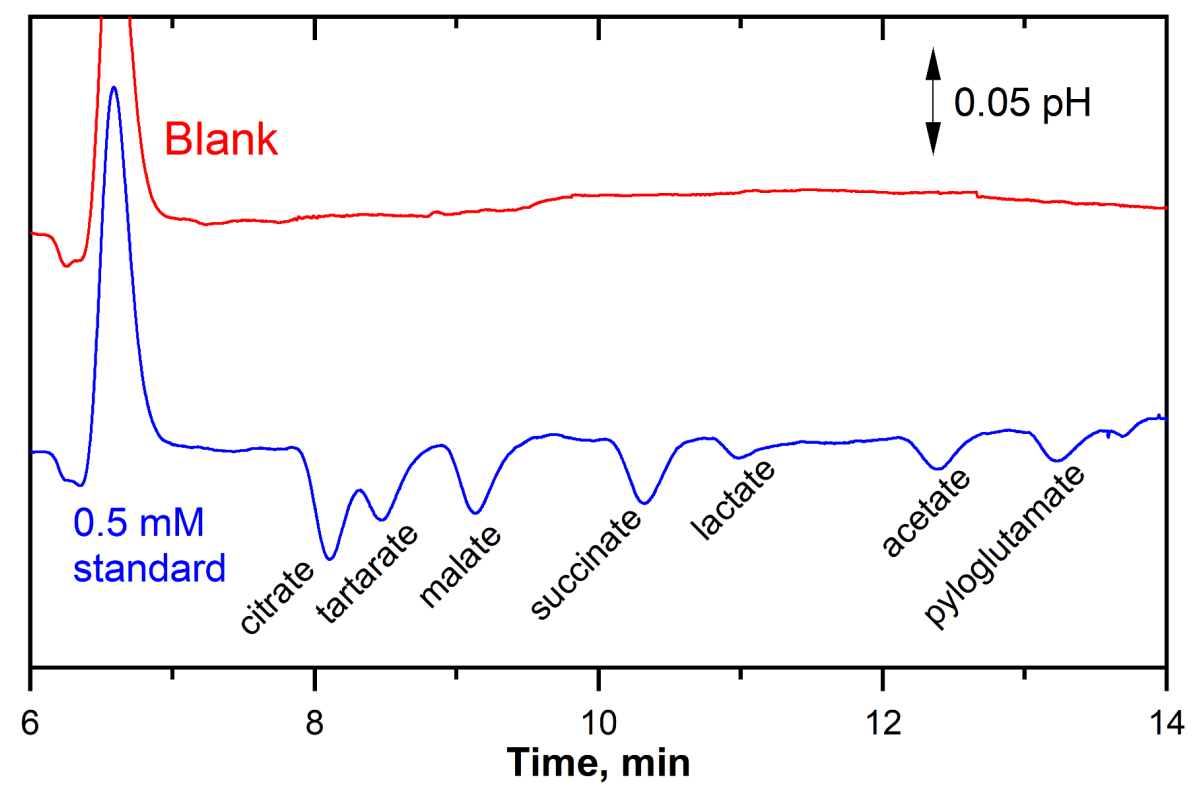

Figure S9 Chromatograms for 0 and $0.5 \mathrm{mM}$ standard mixtures. 

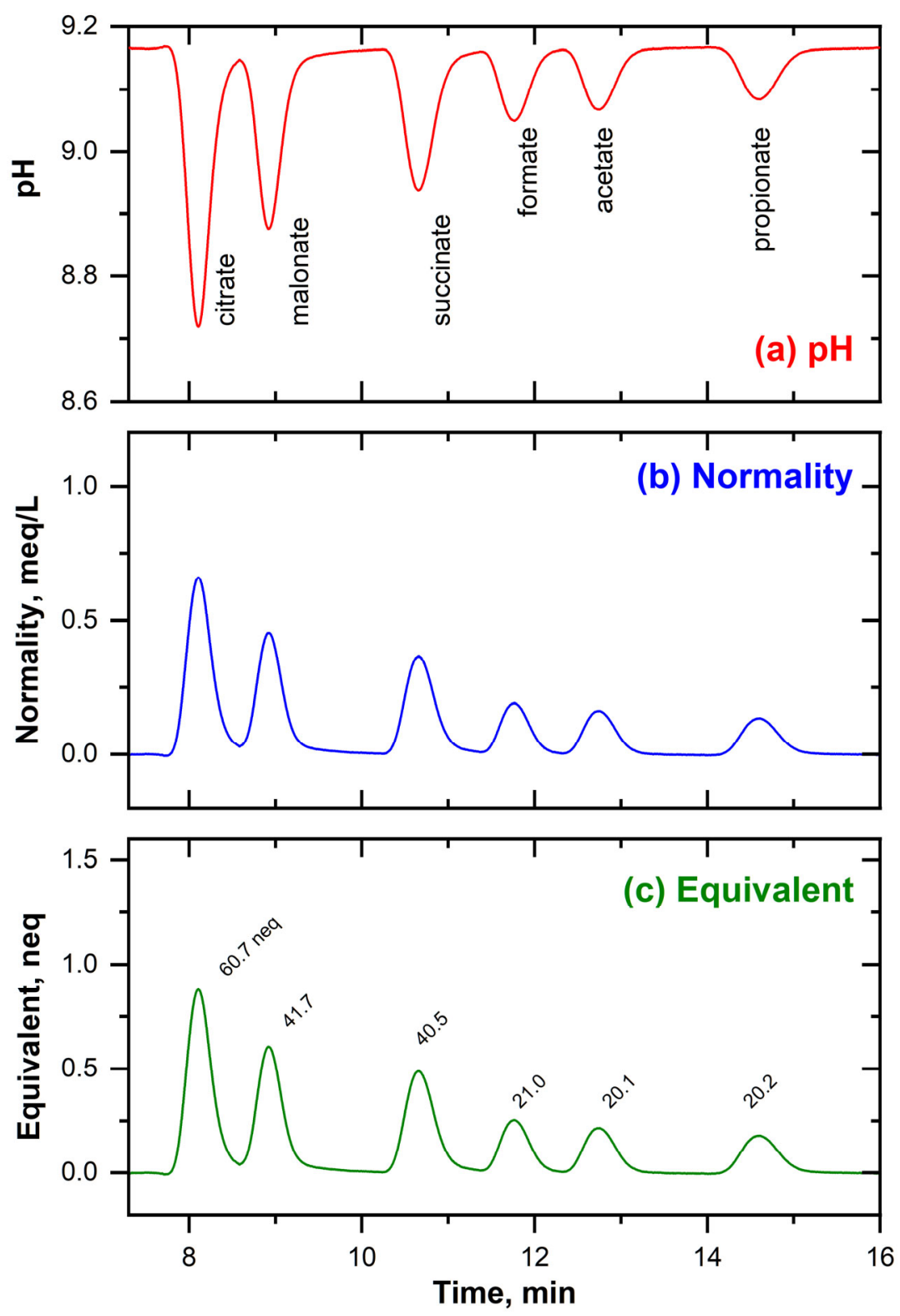

Figure S10 Chromatogram conversions from (a) $\mathrm{pH}$ to (b) normality and (c) equivalents of acids. The number in (c) is sum of the equivalent for each peak. 


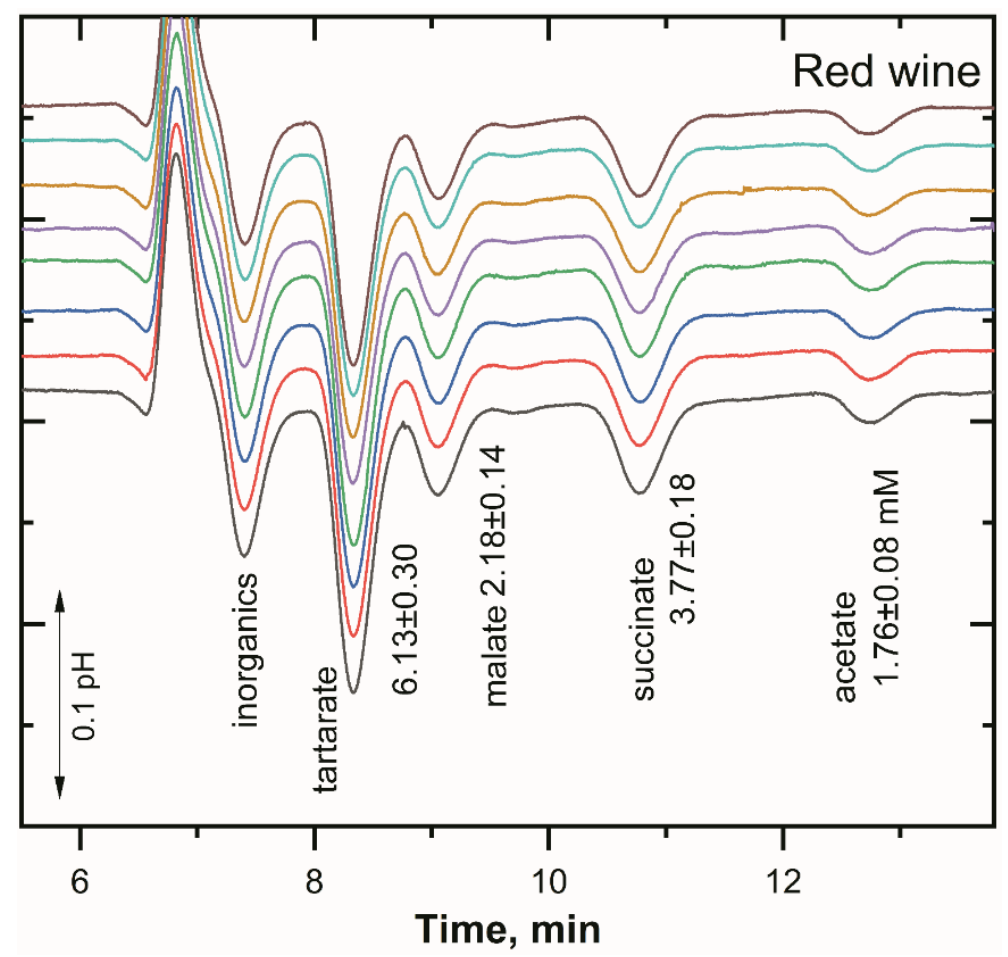

Figure S11 Reproducibility of the $\mathrm{pH}$ detection with a red wine sample without pretreatment. 


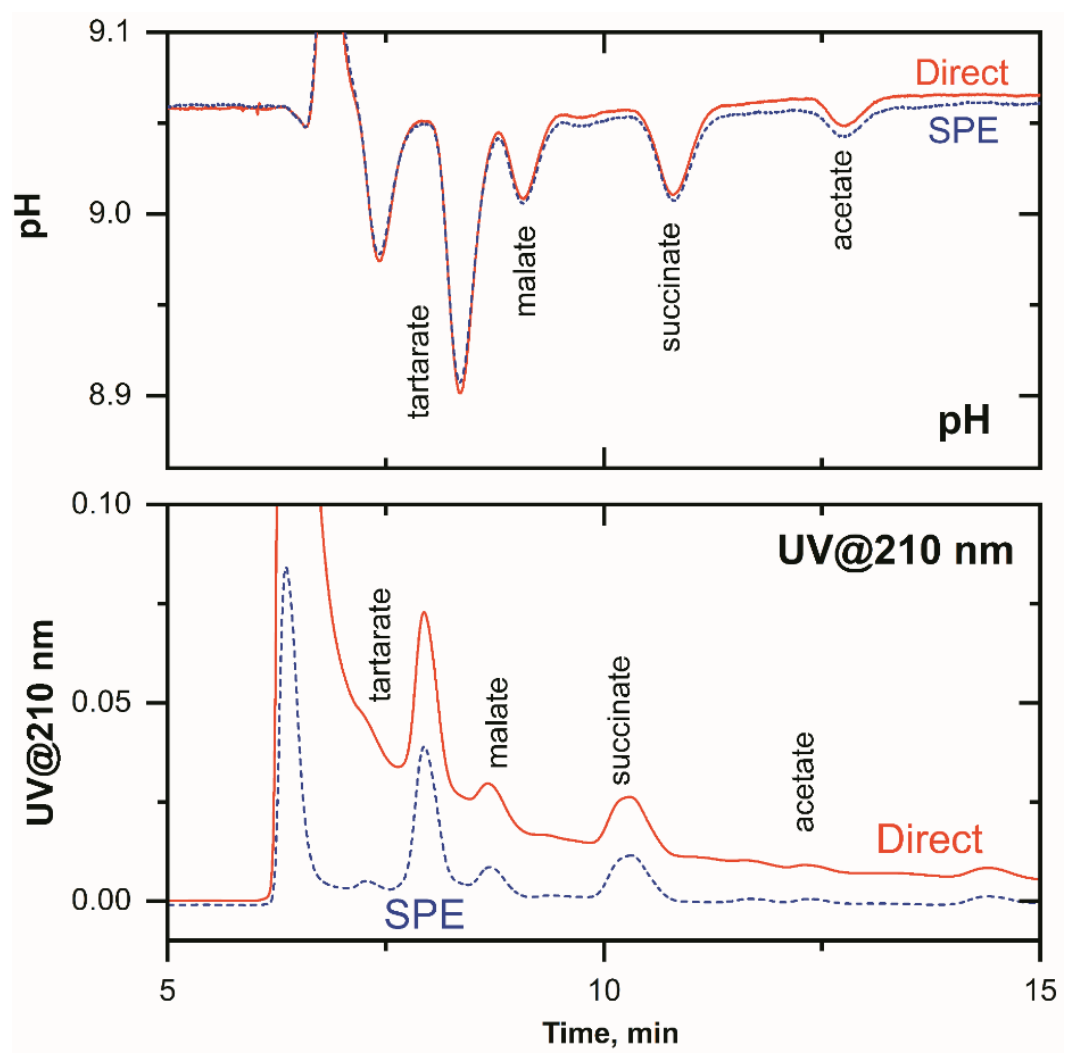

Figure S12 Comparison of the effects of SPE for pH-detector and UV direct detection. The SPE cartridge was a hydrophobic styrene-divinylbenzene copolymer (Intersep ${ }^{\circledR}$ Slim-J mini RP-1, www.gls.co.jp) 
Table S3 The concentrations of organic acids determined with the present pHD and post-column BTB method (mM)

\begin{tabular}{|c|c|c|c|c|c|c|c|c|c|c|c|c|c|c|c|c|c|c|c|c|c|c|c|c|}
\hline \multirow[b]{3}{*}{ Red wine-1 } & \multicolumn{6}{|c|}{ Citrate } & \multicolumn{6}{|c|}{ Tartrate } & \multicolumn{6}{|c|}{ Malate } & \multicolumn{6}{|c|}{ Succinate } \\
\hline & \multicolumn{3}{|c|}{ ВTB } & \multicolumn{3}{|c|}{$\mathrm{pHD}$} & \multicolumn{3}{|c|}{ ВТВ } & \multicolumn{3}{|c|}{$\mathrm{pHD}$} & \multicolumn{3}{|c|}{ ВТВ } & \multicolumn{3}{|c|}{$\mathrm{pHD}$} & \multicolumn{3}{|c|}{ ВТВ } & \multicolumn{3}{|c|}{$\mathrm{pHD}$} \\
\hline & 2.19 & \pm & 0.03 & 2.11 & \pm & 0.11 & 18.4 & \pm & 0.20 & 20.6 & \pm & 0.84 & 6.35 & \pm & 0.18 & 7.13 & \pm & 0.32 & 2.42 & \pm & 0.23 & 2.77 & \pm & 0.12 \\
\hline Red wine-2 & 2.84 & \pm & 0.12 & 3.05 & \pm & 0.07 & 17.0 & \pm & 0.21 & 17.2 & \pm & 0.65 & 1.30 & \pm & 0.14 & 1.51 & \pm & 0.10 & 4.94 & \pm & 0.15 & 5.17 & \pm & 0.01 \\
\hline Red wine-3 & 5.03 & \pm & 0.05 & 4.74 & \pm & 0.07 & 21.8 & \pm & 0.17 & 21.1 & \pm & 0.65 & 9.08 & \pm & 0.05 & 9.38 & \pm & 0.10 & 5.56 & \pm & 0.05 & 5.72 & \pm & 0.01 \\
\hline Sake-1 & 1.27 & \pm & 0.03 & 1.29 & \pm & 0.02 & & & & & & & 0.85 & \pm & 0.06 & 0.70 & \pm & 0.02 & 1.60 & \pm & 0.09 & 1.67 & \pm & 0.16 \\
\hline Sake-2 & 1.24 & \pm & 0.06 & 1.34 & \pm & 0.21 & & & & & & & 0.66 & \pm & 0.02 & 0.61 & \pm & 0.03 & 1.80 & \pm & 0.05 & 1.91 & \pm & 0.22 \\
\hline Sake-3 & 1.50 & \pm & 0.05 & 1.42 & \pm & 0.03 & & & & & & & 1.02 & \pm & 0.03 & 1.12 & \pm & 0.03 & 1.98 & \pm & 0.01 & 2.23 & \pm & 0.05 \\
\hline $\begin{array}{l}\text { Sweetened } \\
\text { sake }\end{array}$ & 0.58 & \pm & 0.01 & 0.51 & \pm & 0.02 & & & & & & & 0.96 & \pm & 0.02 & 1.03 & \pm & 0.11 & & & & & & \\
\hline Soy sauce & 3.60 & \pm & 0.02 & 3.75 & \pm & 0.04 & & & & & & & & & & & & & & & & & & \\
\hline $\begin{array}{c}\text { Broth mixed } \\
\text { soy sauce }\end{array}$ & 2.28 & \pm & 0.04 & 2.39 & \pm & & & & & & & & & & & & & & 0.78 & \pm & 0.00 & 0.82 & \pm & 0.03 \\
\hline $\begin{array}{c}\text { LOD } \\
(3 \mathrm{~S} / \mathrm{N})\end{array}$ & 0.06 & & & 0.05 & & & 0.08 & & & 0.05 & & & 0.10 & & & 0.05 & & & 0.11 & & & 0.05 & & \\
\hline
\end{tabular}

*These were analyzed with 10 times dilution. In the table, the concentrations in diluted samples are shown. 
Table S3 The concentrations of organic acids determined with the present pHD and post-column BTB method (mM) (continued)

\begin{tabular}{|c|c|c|c|c|c|c|c|c|c|c|c|c|c|c|c|c|c|c|}
\hline \multirow[b]{3}{*}{ Red wine-1 } & \multicolumn{6}{|c|}{ Lactate } & \multicolumn{6}{|c|}{ Acetate } & \multicolumn{6}{|c|}{ Pyroglutamate } \\
\hline & \multicolumn{3}{|c|}{ BTB } & \multicolumn{3}{|c|}{$\mathrm{pHD}$} & \multicolumn{3}{|c|}{ BTB } & \multicolumn{3}{|c|}{ pHD } & \multicolumn{3}{|c|}{ BTB } & \multicolumn{3}{|c|}{$\mathrm{pHD}$} \\
\hline & 2.39 & \pm & 0.05 & 2.21 & \pm & 0.75 & 4.82 & \pm & 0.06 & 4.75 & \pm & 0.14 & & & & 0.62 & \pm & 0.04 \\
\hline Red wine-2 & 18.6 & \pm & 0.89 & 18.1 & \pm & 0.19 & 7.24 & \pm & 0.18 & 7.36 & \pm & 0.56 & & & & 0.71 & \pm & 0.20 \\
\hline Red wine-3 & 14.9 & \pm & 0.08 & 14.8 & \pm & 0.19 & 6.09 & \pm & 0.02 & 5.90 & \pm & 0.56 & 1.09 & \pm & 0.00 & 0.85 & \pm & 0.20 \\
\hline Sake-1 & 13.9 & \pm & 0.02 & 12.4 & \pm & 0.48 & & & & & & & 1.10 & \pm & 0.03 & 1.05 & \pm & 0.03 \\
\hline Sake-2 & 9.09 & \pm & 0.22 & 8.62 & \pm & 0.52 & 1.38 & \pm & 0.17 & 1.24 & \pm & 0.24 & 0.71 & \pm & 0.01 & 0.70 & \pm & 0.01 \\
\hline Sake-3 & 4.32 & \pm & 0.15 & 4.32 & \pm & 0.27 & 0.91 & \pm & 0.03 & 1.00 & \pm & 0.05 & 0.82 & \pm & 0.04 & 0.84 & \pm & 0.14 \\
\hline \multicolumn{19}{|l|}{$\begin{array}{l}\text { Sweetened } \\
\text { sake }\end{array}$} \\
\hline Soy sauce* & 3.51 & \pm & 0.19 & 3.35 & \pm & 0.07 & 4.29 & \pm & 0.12 & 4.44 & \pm & 0.01 & 1.94 & \pm & 0.16 & 1.83 & \pm & 0.01 \\
\hline $\begin{array}{l}\text { Broth mixed } \\
\text { soy source* }\end{array}$ & 4.54 & \pm & 0.14 & 5.18 & \pm & 0.09 & 5.05 & \pm & 0.01 & 5.23 & \pm & 0.02 & 2.00 & \pm & 0.08 & 1.91 & \pm & 0.03 \\
\hline $\begin{array}{l}\text { LOD } \\
(3 \mathrm{~S} / \mathrm{N})\end{array}$ & 0.21 & & & 0.08 & & & 0.16 & & & 0.08 & & & 0.18 & & & 0.08 & & \\
\hline
\end{tabular}

*These were analyzed with 10 times dilution. In the table, the concentrations in diluted samples are shown. 